\title{
PROFIL PSIKOLOGIS SIMPTOM PSIKOPATIK PADA NARAPIDANA WANITA KASUS PEMBUNUHAN DI LEMBAGA PEMASYARAKATAN KLAS IIA WANITA SUKAMISKIN BANDUNG
}

\author{
Aris Budi Utomo \\ Fakultas Psikologi, Universitas Padjadjaran \\ E-mail: aris.budi.utomo@unpad.ac.id
}

\begin{abstract}
ABSTRAK: Penelitian ini bertujuan untuk melihat gambaran mental health pada narapidana wanita dan kaitannya dengan kepribadian psikopatik. Sebanyak 7 narapidana dengan kasus pembunuhan dipilih berdasarkan hasil screening data. Tiga faktor yang menjadi pertimbangan, yaitu: motif kejahatan, residivis, dan rekomendasi dari petugas sipir. Waktu pelaksanaan penelitian dilaksanakan selama 2 minggu, bertempat di Lembaga Pemasyarakatan Klas IIA Wanita Sukamiskin - Bandung. Rancangan penelitian ini berupa penelitian deskriptif kualitatif, yang bertujuan untuk memperoleh: 1) gambaran mental health, 2) klasifikasi gangguan psikopatik dan 3) simptom psikopatik yang dominan. Hasil yang diperoleh, yaitu: 1) gambaran mental health yang diperoleh dari 7 orang narapidana yaitu dua orang subjek mengalami stres sedangkan 5 orang lainnya berada pada kondisi mental health yang sehat tanpa merasa stres; 2) Satu orang tergolong psikopat; 3) Lima lainnya memiliki kecenderungan psikopat, dan 4) Satu memililiki kecenderungan rendah untuk menjadi psikopat. Selain itu, terdapat 2 simptom psikopatik yang dominan yaitu: pathological lying, dan impulsiveness. Kesimpulan dan rekomendasi terhadap 7 orang narapidana pembunuhan di atas adalah bahwa 1 orang yang tergolong psikopat perlu pembinaan psikoedukasi yang intensif dan pemisahan ruangan. 1 orang kecenderungan psikopat rendah perlu di konseling sebagai preventif, dan 5 orang yang masih tergolong mental health sehat tanpa stres perlu dilatih untuk tidak berbohong akan masalah serta pengendalian akan impulsivitasnya.
\end{abstract}

Kata kunci: Psikopatik, Mental health, Psychopathic Checklist - Revised (PCL-R), General Health Questionare-28 (GHQ)28, Narapidana Wanita

ABSTRACT: Nowadays, many women have graduated from higher level education. One of the effects is high level of competition among women in many areas of life. The feminine side of many women have been transformed, gradually, to masculinity, characterized by power and aggression. Many women sometimes use an aggressive way to get what they want, including ways that are against the law. This phenomenon has attracted researchers to study the mental health of female inmates, and its relation to psychopathic personality disruption. Seven female inmates, in Sukamiskin Penitentiary Institute Class IIA - Bandung, who were convicted based on fraud cases, were chosen as subjects of this study. The results showed that: in terms of Mental Health Representation, 2 subjects had stress problem, and the other 5 were in the healthy mental state without stress indication. One subject was classified as Psychopath and the other 5 subjects had some tendencies to Psychopath, and 1 subject had a very low tendency to become a Psychopath. There were 2 dominant Psychopathic Symptoms found: pathological lying, and impulsiveness. It can be summarized and recommended that among the 7 subjects, one who is classified as psychopath need to receive an intensive psychoeducation and is placed in a separate room. The other one subject who has a low tendency of psychopathic symptom need counseling as prevention. As for the other 5 subjects who have healthy mental health without stress need to be trained to control their impulse to lie.

Key words: Psychopathic, Psychopathic Checklist - Revised (PCL-R), General Health Questionare-28 (GHQ)-28, Female Inmates

\section{PENDAHULUAN}

Saat ini, banyak wanita yang menempuh pendidikan dengan tingkat yang lebih tinggi. Hal tersebut menim-bulkan adanya persaingan antara satu wanita dengan wanita lainnya. Sisi feminin yang umumnya dimiliki seorang wanita, perlahan-lahan mengalami pergeseran, mereka juga menunjukkan sisi maskulin dengan power dan agresi, Vira W.R. 2009. Seringkali banyak wanita menggunakan cara yang lebih agresif atau bahkan mengarah kepada tindakan kriminal. Di penjara sendiri, banyak wanita yang melakukan agresivitas dalam kesehariannya. Sebuah penelitian dari Wheaton (2009) menunjukkan bahwa 93.6\% narapidana wanita pernah menjadi korban agresivitas, melakukan tindakan agresif ataupun dua-duanya. Selain itu penelitian dari Ben Horin
(2001) menunujukkan bahwa agresi relasional memiliki korelasi dengan kepribadian psikopatik. Fenomena ini yang menimbulkan ketertarikan peneliti untuk melihat gambaran mental health pada narapidana wanita serta kaitannya dengan gangguan kepribadian psikopatik.

Pada tahun 1941, Dr. Hervey Cleckley mempublikasikan buku The Mask of Sanity, sebuah pendekatan baru untuk psikopat. Hingga saat itu, psikopatik dimengerti sebagai kegilaan tanpa delirium, kegilaan moral dan inferioritas psikopatik. Clekley membentuk 16 trait yang membentuk pola dan perilaku psikopat, di antaranya adalah manipulatif, tidak adanya rasa tanggung jawab, self-centeredness, shallowness, dan tidak adanya rasa empati atau kecemasan.

Robert Hare mengamati bahwa pada tahun 1970-an para peneliti dalam bidang psikopatik 
menggunakan banyak klasifikasi yg berbeda untuk menentukan kepribadian psikopatik seperti misalnya kategori yang bedasarkan dari Minnesota Multiphasic Personality Inventory dan the California Psychological Inventory. Hare mengatakan bahwa oleh karena alat tes tersebut berupa self-report inventory, tidaklah sulit bagi seorang psikopat untuk menemukan struktur tes tersebut dan memanipulasi jawaban mereka saat mengisi tes. Oleh karena asesmen harus menyertakan juga teknik observasi dan ketrampilan wawancara yang kuat.

Hare pada akhirnya memutuskan untuk bereksperimen dengan metode asesmen dan pengukuran yang berbeda, menggunakan sistem rating dari deskripsi Cleckley. Ia memutuskan untuk melakukan asesmen dengan sistem kuantifikasi. Ia mempublikasikan hasil penelitiannya dengan 22 item skala untuk mengasess kepribadian psikopatik pada tahun 1980. Hasil ini perlu diperbandingkan dengan asemen kualitatif.

Psikopatik adalah sebuah gangguan kepribadian (Hare dalam Without Concience, didefinisikan sebagai sekelompok perilaku yang khas dimana dilihat oleh masyarakat sebagai perilaku yang merendahkan, lihat Brand, 2011. Dalam publikasi lainnya, Hare mengatakan bahwa diantara ciri yang ada pada psikopat, ciri yang paling buruk adalah pengabaian akan hak-hak orang lain dan kecenderungan untuk berperilaku seperti predator dan perilaku kekerasan. Tanpa rasa bersalah, daya tarik seorang psikopat dapat mengeksploitasi seseorang untuk keuntungan mereka sendiri. Mereka kurang memiliki empati, rasa tanggung jawab. Mereka memanipulasi, berbohong dan memperdaya orang lain tanpa memperhatikan perasaannya. Semua ciri-ciri tersebut dimiliki oleh orang yang tergolong berperilaku psikopat lihat Encyclopedia of Mental Disorders 2011.

Penelitian lebih lanjut menunjukkan bahwa psikopat memiliki kemungkinan yang lebih besar untuk melakukan berbagai jenis kejahatan, lebih kejam, lebih memiliki kemungkinan untuk menjadi seorang residivis, mereka... dan cenderung kurang merespon treatment daripada yang lainnya. Naik ke atas sebelum cenderung...... mereka mudah untuk menjadi bagian dari populasi namun cenderung menikam dari belakang. Cleckley mengatakan bahwa oleh karena sulit membedakan simptom-simptom yang ada, terminologi psikiatris tidak dapat digunakan untuk mengerti dan membedakan orang-orang seperti itu. Untuk melihat simptom-simptom psikopatik yang ada, seorang psikopat perlu untuk terhubung dengan kehidupan sosial secara penuh.

Banyak orang yang berfikiran bahwa psikopat biasanya pembunuh atau tahanan penjara. Namun, psikopat sebenarnya dapat menjadi pengusaha, politikus, CEO dan individual sukses lainnya yang mungkin tidak pernah masuk lembaga pemasyarakatan dan tidak melakukan kejahatan yang bersifat kriminal, lihat pula Kline, 2011. Namun mereka melakukan kejahatan dengan jenis lain seperti mengeksploitasi dan membiarkan mereka sengsara. Mereka terbukti menjadi karyawan yang berbahaya, pengusaha yang licik, atau pejabat yang tidak bermoral dan menyalahgunakan posisi mereka untuk mengorbankan orang lain dan memperkaya diri sendiri.

Apa yang hilang dari seorang psikopat adalah kualitas bahwa seseorang bergantung untuk hidup dalam keselarasan sosial. Selain itu biasanya psikopat lebih bersifat predator, termotivasi oleh tujuan yang tidak dapat diidentifikasi, tidak akan melakukan kejahatan berdasarkan perasaan seperti misalnya pertengkaran keluarga. Mereka bereaksi, pamer atau mengontrol sebagai sarana untuk membuktikan pada diri sendiri. Kebanyakan, kejahatan mereka cukup sadis, dan mereka merasakan gairah daripada rasa bersalah.

Mental health menggambarkan kondisi pemfungsian yang dimiliki seseorang, apakah dikatakan sehat atau sedang dalam kondisi distress. Dengan mengukur mental health dapat diperoleh data yang menunjang kemungkinan kecenderungan simptom psikopatik yang dimilliki narapidana. Seorang narapidana yang memiliki kecenderungan psikopatik memungkinkan memiliki tingkat stres yang rendah atau sama sekali tidak memilikinya, karena mereka merasa tidak terbebani dengan lingkungan. Oleh karena itu akan dilakukan dalam penelitian ini akan dilakukan pengukuran mental health dengan menggunakan General Health Questonare (GHQ-28) disusun oleh Goldberg (1979). Sedangkan untuk mengetahui adakah kecenderungan simptom psikopatik yang dimiliki dengan menggunakan Psychopathic Checklist-Revised $(P C L-R)$ dari Robert D. Hare dan Craig. S (2003). Kedua hasil pengukuran tersebut saling mempengaruhi untuk melihat secara keseluruhan apakah mereka tergolong psikopatik atau tidak

\section{METODE}

Penelitian dilakukan di Lembaga Pemasyarakatan (Lapas) Klas IIA Wanita Sukamiskin, Arcamanik, Kota Bandung. Dengan waktu pelaksanaan penelitian selama 2 minggu, 7 orang narapidana dengan kasus pembunuhan dipilih berdasarkan screening data yang diperoleh dari hasil observasi pre-test individual assesment in group, berupa "Somewhere Over the Rainbow" untuk menemukan simptom-simptom psikopatik, dan data dari pihak instansi. Tiga faktor yang menjadi pertimbangan, yaitu: motif kejahatan, residivis, dan rekomendasi dari petugas sipir. Setelah itu peneliti menanyakan kesediaan mereka untuk mengikuti serangkaian pemeriksaan. Rancangan penelitian ini berupa penelitian deskriptif, yang bertujuan untuk memperoleh: 1) gambaran mental health, 2) klasifikasi gangguan psikopatik, dan 3) simptom psikopatik yang dominan.

Pengambilan data, dilakukan dalam dua bentuk, yaitu: 1) individual assessment dengan menggunakan 
General Health Questionare-28 (GHQ)-28 dan Psychopathic Checklist - Revised (PCL $-R$ ) dari Robert D. Hare dan Craig. S (2003), dan 2) individual assessment in group setting berupa games.

General Health Questionnaire (GHQ-28) disusun oleh Goldberg (1979), dengan maksud untuk mengidentifikasi pengalaman individu ketika mengalami gangguan yang dapat menghambatnya berfungsi optimal ketika menghadapi situasi distress baru. Tes GHQ ini mengidentifikasi ketika individu mengalami gangguan pemfungsiannya secara "sehat", dan menampilkan distress baru. Terdapat 4 elemen distress yang diukur melalui tes ini, yaitu: hipokondriasis, kecemasan/ insomnia, gangguan sosial, dan depresi. Terdapat 28 pertanyaan dengan pilihan jawaban "Ya dan "Tidak". Pemberian skor 0 untuk pilihan "Tidak" dan 1 untuk pilihan "Ya". Untuk total skor metoda GHQ, yaitu antara 0 dan 28. Nilai cut-off skor (Norma) adalah 5/6, berarti bahwa skor total $\geq 6$ menunjukkan adanya gejala stres.

Psychopathic Checklist - Revised (PCL $-R$ ) disusun oleh Robert D. Hare and Craig S. Neumann (2003), tujuan alat diagnostik tersebut untuk mengukur kecenderungan psikopatik atau antisosial pada seseorang. Hare sudah melakukan beberapa kali revisi hingga terbentuk menjadi 20 item, yang sekarang disebut Psychopathy Checklist-Revised (PCL-R) dan dilengkapi dengan dasar wawancara semi terstruktur. Item-item PCL-R dibagi menjadi dua faktor dasar yaitu fitur afektif/interpersonal (interpersonal) dan gaya hidup menyimpang secara sosial (social deviance). Interpersonal factors terdiri atas: glibness and superficial charm, self-worth or grandiosity, pathological lying, lack of remorse or guilt, cunning or manipulative, shallow affect or emotional poverty, callousness/lack of empathy, dan failure to accept one's responsibilities. Sedangkan social deviance factors terdiri atas: need for stimulation easiliy bored, parasitic lifestyle, poor behavior control, no realistic long-term goals, early behavioral problems, lack of realistic long-terms goals, impulsivity, irresponsibility, juvenile deliquency, revocation of conditional release, many short-term marital relationships, promiscuity, dan criminal versatility.

Seseorang diukur dengan skala mulai dari 0 , yang berarti tidak terdapat tanda manifestasi hingga 2 , yang berarti pasti terdapat manifestasi. Jumlah skor total yaitu 4, dengan kategori: a) skor 0-5 menunjukkan tidak adanya kecenderungan psikopatik; b) 6-22 menunjukkan adanya kecenderungan psikopatik; dan c) seseorang dapat didiagnosa sebagai seorang psikopat apabila jumlah nilainya 30 hingga 40. Dikarenakan range tengah yang ditunjukkan terlalu besar. Oleh karena itu peneliti membagi menjadi kecenderungan psikopatik rendah, sedang, dan tinggi.

Individual Assessment in Group Setting. Narapidana diberikan 4 (empat) jenis games, yaitu, I Want Candy, Hidrogen Helium, dan Win as much as You
Can. Secara garis besar, ketiga games tersebut memberi kesempatan adanya interaksi antara yang satu dengan yang lain. Kondisi tersebut dapat membantu untuk menunjukkan adakah simptom-simptom psikopatik pada masing-masing individu ketika dihadapkan pada suatu group setting. Bagaimana mereka menjalin relasi, memperlakukan rekan, mematuhi aturan permainan dan menyusun strategi untuk memenangkan permainan.

Pengolahan data selanjutnya dilakukan dalam bentuk kuantitatif dan kualitatif. Pengolahan kuantitatif, Pertama dari hasil gambaran mental health narapidana wanita, apakah mereka tergolong stress atau tidak. Hasil ini berupa total skor General Health Questionare-28 (GHQ)-28. Kedua, diperoleh total skor dari Psychopathic Checklist - Revised $(P C L-R)$ yang menunjukkan pakah mereka memiliki kecenderungan psikopatik atau tidak. Ketiga dari frekuensi skor masing-masing indikator. Pengolahan kualitatif diperoleh dari data demografi dan hasil observasi individual assessment in group setting berupa games. Setelah itu ditarik kesimpulan dalam bentuk gambaran deksriptif umum jenis kejahatan pembunuhan.

\section{HASIL DAN PEMBAHASAN}

Diperoleh dari 7 responden data demografi sebagai berikut:

Hasil yang diperoleh dari 7 subyek kasus pembunuhan, 5 orang $(71,43 \%)$ tidak menunjukkan gejala stres, sementara 2 orang mengalami stres (28,57\%). Dari 2 orang yang mengalami stres, 1 orang termasuk dalam golongan kecenderungan psikopat dalam level tinggi dan seorang lagi masuk dalam golongan kecenderungan psikopat dalam level sedang. Mereka mengalami stres karena merasa kesepian sudah bertahun-tahun menghuni LP namun tidak dikunjungi oleh keluarganya. Sedangkan dari 5 orang yang berada dalam kondisi tidak stres, terdapat 1 orang termasuk psikopat, 2 orang kecenderungan psikopat dalam level tinggi, dan 2 orang cenderung psikopat dalam level rendah.

Sedangkan profil Psychopathic ChecklistRevised (PCL-R) yang diperoleh dari 7 subjek, adalah sebagai berikut:

Berdasarkan tabel 2 dapat dijelaskan sebagai berikut. Dari tabel satu subjek (14,29\%) terindikasi masuk kategori psikopat dengan skor $35(++)$, enam lainnya termasuk ke dalam kecenderungan psikopat, rinciannya sebagai berikut:

- Tinggi: dua subjek $(28,57 \%)$ dengan skor $28(+)$ dan $26(+)$,

- Rata-rata: dua subjek $(28,57 \%)$ dengan skor 21 (0ka) dan 20 (0ka),

- Rendah: dua (2) subjek $(28,57)$ dengan skor 13 (-) dan $9(-)$ 
Berdasarkan hasil PCL-R diperoleh bahwa dari seluruh kasus pembunuhan, terdapat 2 simptom yang dominan yaitu:

1. Pathological lying. Semua klien yaitu 7 orang $(100 \%)$ menyampaikan kebohongan pada pemeriksa baik dalam rangka untuk menampilkan citra diri yang baik, atau bahkan kebohongan dilakukan sematamata hanya mempermainkan pemeriksa. Bahkan 1 dari 7 orang $(14,29 \%)$ tersebut menyampaikan kebohongan setelah seharian dilakukan pengambilan data oleh pemeriksa. Pada hari kedua ia mengakui bahwa hari pertama semua yang disampaikannya adalah kebohongan. Jumlah skor total untuk pathological lying ini juga yang terbesar, yaitu 14, atau menghasilkan nilai rata-rata $=1,71$.

2. Impulsiveness. 6 dari 7 orang $(85,71 \%)$ pelaku pembunuhan menunjukkan perilaku impulsif. Mereka mudah terpancing emosinya. Ketika marah atau kesal, mereka cenderung menunjukkan agre-sivitas, baik dalam bentuk verbal maupun perilaku. Kecuali 1 orang $(14,29 \%)$ yang tidak menunjukkan perilaku impulsif, ia menujukkan perilaku yang terkendali mengikuti norma dan aturan yang diberlakukan. Dalam kasus pembunuhan ini ia tidak terlibat langsung dalam pembunuhan, melainkan hanya memberikan alamat pada pelaku pembunuhan.

3. Untuk pathological lying dan cunning/manipulative, semua subjek (100\%) menunjukkan perilaku tersebut, namun taraf untuk cunning/manipulatif tidak setinggi taraf pathological lying.

Dilihat dari total skor, menonjolnya simptom pathological lying dan impulsiveness menunjukkan kekurang mampuan sebagian besar pelaku pembunuhan dalam mengendalikan dorongan-dorongannya. Lebih lanjut lagi untuk menutupi perilaku kejahatan yang telah dilakukannya mereka melakukan kebohongan untuk menutupinya agar tidak diketahui oleh orang lain

Secara umum, dapat dilihat bahwa bahwa narapidana yang tergolong psikopat dan yang memiliki kecenderungan $\mathrm{ke}$ arah psikopat memiliki mental health yang tergolong sehat atau tidak dalam kondisi stres. Sedangkan yang tidak memiliki kecenderungan psikopat menunjukkan bahwa ia berada dalam kondisi stres. Data tersebut menunjukkan kesesuaian dan memperkuat bahwa seseorang yang tergolong psikopat memang memiliki tingkat stres yang rendah. Mereka tidak memperdulikan stimulasi emosional yang terdapat di lingkungannya atau dengan kata lain sensitivitas yang tergolong rendah atau bahkan sama sekali tidak ada, mereka lebih banyak berfokus pada dirinya sendiri.

Narapidana tersebut dibesarkan dari keluarga yang tidak harmonis. Anak-anak tidak mempunyai hubungan baik dan tidak mendapatkan kasih sayang dari kedua orang tua. Penanaman nilai di keluarga cenderung lemah sehingga anak tidak mengerti mana yang boleh Ia lakukan dan mana yang tidak boleh Ia lakukan. Oleh karena mereka tidak ditanamkan mengenai aturan dengan baik, mereka cenderung melakukan apa yang mereka ingin lakukan tanpa mengetahui hal tersebut salah atau benar dan kurang memiliki keahlian untuk mengontrol diri mereka sendiri.

Pada saat remaja, lingkungan khususnya teman memiliki dampak besar bagi perkembangan kepribadian seseorang. Pada saat seseorang dalam tahap pencarian jati diri, Ia cenderung akan mengikuti arus yang ada. Apalagi ketika seseorang memiliki sistem nilai yang lemah pada dirinya, Ia akan mudah terseret pada hal yang negatif dalam pergaulan. Dalam kasus pembunuhan, lingkungan yang terdapat di sekitar mereka cenderung lingkungan yang negatif seperti mabuk-mabukan dan free sex, oleh karena penanaman nilai yang kurang

Tabel 1. Data demografi

\begin{tabular}{|c|c|c|c|c|c|c|c|c|c|}
\hline No & Umur 1 & Umur 2 & Hukuman & Pendidikan & Posisi & Agama & Status Pernikahan & $\begin{array}{c}\text { Latar } \\
\text { Belakang } \\
\text { Leluarga }\end{array}$ & $\begin{array}{c}\text { Suku } \\
\text { bangsa }\end{array}$ \\
\hline 1 & 29 & 30 & 7 & SMA & 1 dari 4 & Islam & Nikah & Utuh & Sunda \\
\hline 2 & 23 & 24 & 6 & SD & 5 dari 5 & Islam & Janda Cerai & $\begin{array}{l}\text { Ayah } \\
\text { Menikah } \\
13 \text { kali }\end{array}$ & Sunda \\
\hline 3 & 18 & 22 & 8 & $\begin{array}{l}\text { Tdk lulus } \\
\text { SD }\end{array}$ & 2 dari 4 & Islam & Janda Cerai & Cerai & Sunda \\
\hline 4 & 24 & 25,8 & 15 & $\begin{array}{c}\text { SMP } \\
\text { (sampai } \\
\text { SMA kls 2) }\end{array}$ & 4 dari 5 & Islam & Nikah & Utuh & Jawa \\
\hline 5 & 52 & 59 & 15 & $\mathrm{~S} 1$ & $\begin{array}{c}4 \text { dari } 5 \\
\text { atau } 1 \\
\text { dari } 2\end{array}$ & Isalam & Nikah & & Jawa \\
\hline 6 & 20 & 21 & 9,5 & SMA & 3 dari 4 & Islam & $\begin{array}{c}\text { Suami (pergi } \\
\text { meninggalkan) }\end{array}$ & Cerai & Sunda \\
\hline 7 & 25 & 28 & 8 & SMA & 4 dari 4 & Islam & Janda Cerai & & Sunda \\
\hline Rata-rata & 27 & & & & & & & & \\
\hline
\end{tabular}

Keterangan: Umur 1: Umur ketika melakukan kejahatan; Umur 2: umur saat pengambilan data 
Table 2. GHQ-28 and PCL-R Score for Murder Case

\begin{tabular}{|c|c|c|c|c|c|c|c|c|}
\hline Subj. & I & II & III & IV & $\begin{array}{c}\text { Total } \\
\text { GHQ-28 }\end{array}$ & Category & $\begin{array}{c}\text { Total } \\
\text { PCL-R }\end{array}$ & Category \\
\hline 1. & 2 & 0 & 2 & 0 & 4 & $\begin{array}{l}\text { Mentally } \\
\text { healthy }\end{array}$ & $35(++)$ & Psychopath \\
\hline 2. & 1 & 0 & 1 & 2 & 4 & $\begin{array}{l}\text { Mentally } \\
\text { healthy }\end{array}$ & $13(-)$ & Low Psychopath Tendency \\
\hline 3. & 1 & 2 & 2 & 4 & 9 & Stressed & $28(+)$ & High Psychopath Tendency \\
\hline 4. & 1 & 1 & 2 & 1 & 5 & $\begin{array}{l}\text { Mentally } \\
\text { healthy }\end{array}$ & $9(-)$ & Low Psychopath Tendency \\
\hline 5. & 5 & 5 & 2 & 3 & 15 & Stressed & $21(0 \mathrm{ka})$ & $\begin{array}{c}\text { Moderate Psychopath } \\
\text { Tendency }\end{array}$ \\
\hline 6. & 0 & 2 & 1 & 0 & 3 & $\begin{array}{l}\text { Mentally } \\
\text { healthy }\end{array}$ & $20(0 \mathrm{ka})$ & $\begin{array}{l}\text { Moderate Psycopath } \\
\text { Tendency }\end{array}$ \\
\hline 7. & 1 & 0 & 1 & 1 & 3 & $\begin{array}{l}\text { Mentally } \\
\text { healthy }\end{array}$ & $30(+)$ & High Psychopath Tendency \\
\hline Total & 11 & 10 & 11 & 11 & & & & \\
\hline $\mathrm{X}$ & 1.57 & 1.42 & 1.57 & 1.57 & 6.14 & & & \\
\hline
\end{tabular}

\section{Profil PCL-R Kasus Pembunuhan}

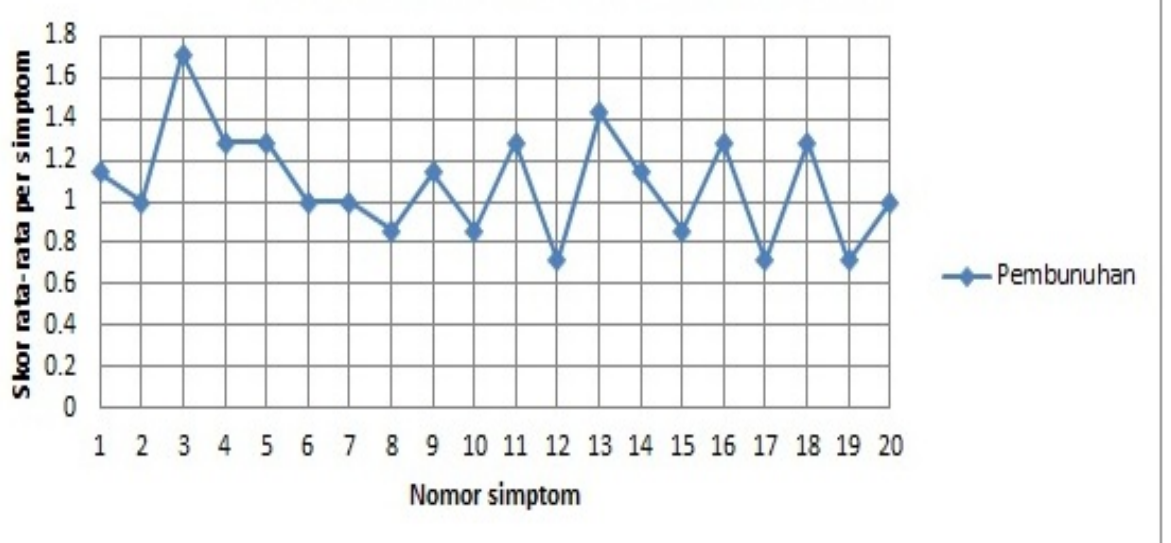

Keterangan Nomor Simptom:

1. Glibness and superficial Charm

2. Grandiose (exaggeratedly high) estimation of self

3. Need for Stimulation

4. Pathological lying

5. Cunning and Manipulativeness

6. Lack of Remorse or guilt

7. Shallow affect (superficial emotional responsiveness)

8. Callousness and lack of empathy

9. Parasitic lifestyle

10. Poor behavioral controls

\section{Gambar 1. Profil PCL-R Kasus Pembunuhan}

baik dari orang tua maka mereka melakukan perbuatan tersebut.

Kontrol diri yang rendah membuat seseorang cenderung melakukan keinginannya. Pada kasus ini terdapat dua simptom yang dominan yaitu pathological lying dan impulsiveness. Pathological lying digunakan untuk mencoba memanipulasi pemeriksa dengan datadata yang mereka berikan dan hal ini kemungkinan berhubungan dengan kebutuhan mereka untuk mendapat stimulasi agar tidak bosan. Sedangkan impulsiveness terlihat dari perilaku mereka yang mudah marah saat sedang bermain games.
11. Sexual promiscuity

12. Early behavior problems

13. lack of realistic longterm goals

14. Implusivity

15. Irresponsibility

16. Failure to Accept Responsibility for own actions

17. Many short team marital relationships

18. Juvenile Delinguency

19. Revocation of Conditional release

20. criminal versatility

\section{SIMPULAN}

Penelitian ini menunjukkan bahwa seorang psikopat cenderung memiliki kondisi mental yang baik. Hal ini terlihat pada salah satunya dalam menghadapi suatu stress. Meskipun mereka memiliki kehidupan emosi yang dangkal, tetapi mereka punya rasa toleransi terhadap stress. Dua simptom yang dominan dalam kasus pembunuhan kelompok wanita adalah muncul pada pathological lying dan impulsiveness. 


\section{DAFTAR PUSTAKA}

Brandt, J.R., Kennedy, W.A., Patrick, C.J., and Curtin, J.J. 1997. Assessment of Psychopathy in a Population of Incarcerated Adolescent Offenders. Psychological Assess ment Copyright 1997 by the American Psychological Association, Inc.1997, Vol. 9, No. 4, 4294351997, Vol. 9, No. 4, 429-435 1040-3590/97. Florida State Universit. Diunduh dari: dionysus. psych.wisc.edu. Pada bulan Juli, 2011.

Ben-Horin, H.C. 2001. The interface between psychopathy and relational aggression in an incarcerated female population. Dissertation Abstracts International: Section B: The Sciences and Engineering, 62(1-B), 590. (UMI No. 3000738)

Blackburn, R. 2011. The Psychology of Criminal Conduct: Theory, Research and Practice. Liverpool, UK: University of Liverpool and Ashworth Hospital. Diunduh dari: books. google.com. Pada bulan Juli.

Encyclopedia of Mental Disorders. 2011 Hare Psychopathy Checklist. Diunduh dari: http:// www.mind disorders. com. Pada bulan Mei.
General Health Questionnaire, 2011. Diundur dari: http://www.gl-assessment.co.uk. Pada bulan Juli.

Hare, R. and, Craig, N.S. 2007. Psychopathy as a Clinical and Empirical Construct. University of British Columbia, Vancouver, British Columbia BC V6T 1Z4; University of North Texas, Denton, Texas 76203-1280. Diunduh dari: www. hare.org. Pada bulan Juli, 2011.

Kline. 2011. Psychopaths: Emotional \& Behavior Responses. Profiling Psychopathology. FSUPC. Diunduh dari: www.kelleykline.com. Pada bulan Juli, 2011.

Ramsland, K., Hare, R. 2011. Expert on The Psychopath. Diunduh dari: http://www. trutv.com/crime/criminal_mind/psychology/ robert_hare/3.html. Pada bulan Juli, 2011.

The Psychopathic Personality. 2010. Diunduh dari: http://www.oregoncounseling.org/handouts/ psychopathicpersonality.htm. Pada bulan Juli, 2011.

Viva, W.R., 2009. Prevalence and Characteristics of Relational Aggression Among Female Inmates. School of Professional Psychology. Paper 153 